\title{
A Collaboration Project on Education for Sustainability: Professional Development Needs of Turkish Preschool Teachers*
}

\section{Sürdürülebilirlik İçin Eğitim Üzerine Bir İşbirliği Projesi: Türkiye'de Okul Öncesi Öğretmenlerinin Mesleki Gelişim İhtiyaçları}

\author{
Savaş PAMUK ${ }^{* *(D)}$ Naciye ÖZTÜRK ${ }^{* * *}$ \\ Deniz PAMUK ${ }^{* * * *}$ (iD) Rıdvan ELMAS ${ }^{* * * * *(i D)}$ \\ Tülin GÜLER-YILDIZ ${ }^{* * * * * *}$ Gelengül HAKTANIR ${ }^{* * * * * * *}$ [iD
}

Received: 07 March 2021

Research Article

Accepted: 13 June 2021

\begin{abstract}
The purpose of this study was to determine the preschool teacher's professional development (PD) needs about education for sustainability (EfS) as the first stage of a PD project. The general knowledge of teachers on sustainable development (SD) and their experience in preparing and implementing EfS activities was investigated. The data were collected from 1126 participants via a survey to determine preschool teachers' knowledge level about SD and their practice to develop a PD program. Most preschool teachers acknowledge the term SD and revealed limited SD knowledge. Organizing learning centers and using outdoor learning environments on EfS were seen as challenging tasks for them. Few of them find themselves competent in family participation efforts for SD.
\end{abstract}

Keywords: Early childhood education, sustainable development, education for sustainability, professional development, preschool teachers.

ÖZ: $\mathrm{Bu}$ çalışma, mesleki gelişim (MG) projesinin birinci aşaması olarak, okul öncesi öğretmenlerinin sürdürülebilirlik için eğitim (SE) ile ilgili MG ihtiyaçlarını incelemektedir. Bu doğrultuda öğretmenlerin sürdürülebilir gelişme (SG) hakkındaki genel bilgileri ile sürdürülebilirlik için eğitim etkinliklerini hazırlama ve uygulama konusundaki deneyimleri araştırılmıştır. Öğretmenlerinin MG ihtiyaçlarını araştırmak için 1126 katılımcıdan bir anket aracılı̆̆ ile veri toplanmıştır. Bulgular, okul öncesi öğretmenlerinin çoğunun sürdürülebilirlik terimi hakkında sınırlı bilgiye sahip olduğunu göstermiştir. Ayrıca, öğrenme merkezlerinin bu amaçla düzenlenmesi ve açık havada öğrenme ortamlarının kullanılması katılımcılar tarafindan zorlu görevler olarak görülmüştür. Katılımcıların küçük bir kısmı sürdürülebilirlik için aile katılımı çalışmalarında kendilerini yeterli bulmaktadır.

Anahtar kelimeler: Okul öncesi eğitim, sürdürülebilir gelişim, sürdürülebilirlik için eğitim, mesleki gelişim, okul öncesi öğretmenleri.

\footnotetext{
* This study is a part of ECEESDPD Project (A Professional Development Project for Early Childhood Education Teachers on Education for Sustainable Development) supported by TÜBİTAK (The Scientific and Technological Research Council of Turkey)

** Corresponding Author: Dr., Akdeniz University, Antalya, Turkey, savaspamuk@gmail.com, http://orcid.org/0000-0001-8661-4262

*** PhD Candidate, Hacettepe University, Ankara, Turkey, nacye231@ hacettepe.edu.tr, https://orcid.org/0000-00024253-8365

**** Assoc. Prof. Dr., Mersin University, Mersin, Turkey, denizkahriman@gmail.com, https://orcid.org/0000-00027028-6097

***** Assoc. Prof. Dr., Afyon Kocatepe University, Afyonkarahisar, Turkey, relmas@aku.edu.tr, http://orcid.org/0000-0001-7769-2525

****** Prof. Dr., Hacettepe University, Ankara, Turkey, tguler@ hacettepe.edu.tr, https://orcid.org/0000-0002-95180336

******* Prof. Dr., Emeritus, Ankara University, Ankara, Turkey, gelengulhaktanir@gmail.com, https://orcid.org/0000-0002-0783-592X
}

Citation Information

Pamuk, S., Öztürk, N., Pamuk, D., Elmas, R., Güler-Yıldız, T., \& Haktanır, G. (2021). A collaboration project on education for sustainability: Professional development needs of Turkish preschool teachers. Kuramsal Ĕgitimbilim Dergisi [Journal of Theoretical Educational Science], 14(4), 586-604. 
Most countries grapple with getting down too many problems: poverty, types of pollution, and loss of biological diversity. Recently, researchers have addressed these problems in many fields such as education, economy, and social policy. Further, politicians and activists put them down on their plan to deal with these problems. Sustainable development (SD) brings forward "meeting the needs of the present without compromising the ability of future generations to meet their own needs" (Brundtland, 1988). Education for Sustainability (EfS) brings people of all ages to assume responsibility to conceive a sustainable future (Bonnett, 1999; UNESCO, 2002). SD was gradually advanced in a multidimensional idea, consisting of pillars of SD environmental, economic, and socio-cultural as a whole constitute EfS (UNESCO, 2005a, 2006). The scope of EfS aims to arrange "people of all walks of life to plan for, cope with, and find solutions for issues that threaten the sustainability of our planet" (UNESCO, 2005b). The existence of qualified teachers is significant to succeed in EfS goals (Panatsa \& Malandrakis, 2018) since children among the age groups are active "agents" to initiate creating chances (UN, 2015). The early years are a "natural starting point" for continuing EfS for all children valued (Dyment et al., 2014), lifespan learning, and societal transformation (Centre for Environment and Sustainability, 2008; UNESCO, 2014). On the other hand, introducing early childhood education practices for sustainability (ECEfS) has been decelerating in recent years (Elliott \& Davis, 2009).

\section{Background}

It is crucial to understand the scope of SD, the value of EfS, and how education affects teachers' concept of sustainability (Panatsa \& Malandrakis, 2018). Teachers shape future citizens' behaviors while their practices are shaped and influenced by their ways of understanding and thinking (Nespor, 1987). Yet, the literature indicates that teachers possess a superficial understanding of SD (Borg et al., 2014). Furthermore, they attend to view EfS through the pillar of the environmental lens, consistently discounting economic and socio-cultural pillars (Borg et al., 2014; Pepper \& Wildy, 2008). The research still focuses on the environmental pillar of SD in EfS (Bascopé et al., 2019). However, understanding the relationship among them has a pivotal role in the holistic awareness of the EfS (Berglund \& Gericke, 2016). Although there is policy and curriculum pressure, many teachers have unnoticed the link between sustainability and the curriculum. (Nicholls \& Thorne, 2017). Barriers to associating integrating EfS in the curriculum is a lack of awareness of its priority (Nicholls \& Thorne, 2017), teachers' conceptions of EfS be limited in scope (Dyment et al., 2015), and inadequate to capture the essence of sustainability and its bearing within the curriculum (Australian Education for Sustainability Alliance, 2014).

\section{The Motivation of the Project and the Study}

According to Inoue et al. (2016), sustainability is a many-faceted concept. There are various groups, such as politicians, scientists and teachers, interpreting it differently. Sustainability as environmental issues rather than socio-cultural and economic pillars are primarily understood by teachers (Hill et al., 2014). Teachers perceive doing naturebased activities as EfS (Elliott \& Davis, 2009). They neglect the economic and sociocultural pillars. However, this sense of direction is not enough to address current sustainability crises and societal transformation (Inoue et al., 2016). Studies are limited to interventional as experimental and action research about EfS conducted with teachers 
and far too little attention has been developed teachers' practices (Güler Y1ldız et al., 2021). Thus, in-service education about sustainability is suggested to understand the scope of sustainability and plan and implement activities in the preschool classroom (Güler Y1ldız et al., 2017). According to Nicholls and Thorne (2017), EfS practices could be improved by professional development (PD) in the classrooms. Therefore, a PD project for preschool teachers on EfS was proposed by Turkish and Korean researchers who came together Education for Sustainable Development World Project initiated by the World Organization for Early Childhood Education (OMEP) and carried out studies together to boost awareness of EfS among children and preschool teachers (Engdahl, 2015; OMEP, 2020).

The project has been funded by the Scientific and Technological Research Council of Turkey (TUBITAK) and the National Research Foundation of Korea (NRF) under the Bilateral Cooperation Program between Turkey and South Korea. The purpose of the project is to increase awareness of EfS among preschool teachers and to support them in integrating EfS into their classroom program and their practices through the medium of the PD modules, which include $7 \mathrm{R}$ themes (reduce, reuse, recycle, respect, reflect, rethink, redistribute) on the context of two countries for two years. Because 7Rs are the appropriate pedagogical framework in the preschool classroom to address EfS (Duncan, 2011; Engdahl \& Rabušicová, 2011), researchers provide professional training to preschool teachers after developing PD modules, and then the modules will be revised concerning the output. Besides, the different teachers will be enrolled in the prospective training, and researchers will follow up the reflection of the training into the school setting. All PD modules and processes will be carried out and negotiated in cooperation with the Korean team (ECEESDPD, 2020).

This study is the first stage of the project and focuses on determining the preschool teacher's PD needs about EfS. The PD modules will be developed based on the findings of the study. Also, this study is significant since minority groups outside the English-speaking culture have been supported by the researchers (Elliott et al., 2020).

\section{A Snapshot of SD/EfS and Preschool Program in Turkey}

Turkey is seeking to reach 17 Sustainable Developmental Goals (SDGs) published in the UN Sustainable Development Agenda in 2015. Moreover, the Eleventh Development Plan for the years 2019-2023, which integrated SDGs, is implementing in Turkey. Concerning the plan, action plans and various projects like Save Your Food Project and Zero Waste are carrying out by ministries (Turkish Ministry of Environment and Urbanization, 2019, 2020). They are applying the projects not only in the public areas but also at the schools. In addition to the government's effort, non-governmental institutions can reach the goals and raise awareness about sustainability for the public and the preschool teachers. For instance, training is conducted to improve teachers' knowledge and practices on the environment by The Turkish Foundation for Combating Soil Erosion (TEMA, 2018).

In Turkey, preschool education refers to 36-72 months old children till starting primary school. In 2013, the preschool program called "Preschool Education Curriculum" as a framework was developed to guide preschool teachers' practices by the Turkish Ministry of National Education (MoNE). The concept of SD is not used in 
this curriculum because it is not thematic but developmental. The curriculum supports all development areas of children in a holistic way. Teachers plan their monthly and daily educational process, classroom activities, assessment of children, and family involvements based on the objectives, which the teacher selects following children's development level and needs. Teachers can add new objectives into the program related to the current local, national, and worldwide issues. Moreover, using outdoor learning environments and organizing learning centers, such as art, science and music, are promoted (MoNE, 2013). Therefore, teachers can associate SD and EfS into their educational process while following up the national program.

The project aims to develop PD modules based on the preschool teachers' needs. Because there is a unique role to guide teachers investigating their knowledge, skills, and dispositions (Inoue et al., 2016). Some studies have been carried out on how teachers defined the concept of sustainability and SD (Güler Y1ldı et al., 2017; Haktanır et al., 2010; Kahriman, 2016; Korkmaz \& Güler Yıldız, 2017; Uğraş \& Zengin, 2019). However, no single study exists on what PD needs of teachers about EfS, and research to date have not yet determined what teachers know and how their skills for sustainability under the national preschool education curriculum in the Turkish context. Therefore, the purpose of this study is to determine the preschool teacher's PD needs about EfS. Determining their needs is critical to prepare modules about ECEfS for the project so their knowledge and skills might be enacted with varied emphasis with PD modules. As a result, the following research questions were determined to investigate preschool teachers' PD needs:

1. What is the general knowledge of preschool teachers on SD and its pillars?

2. What is preschool teachers' experience in preparing and implementing EfS activities in the classroom?

3. What are the PD needs of preschool teachers for EfS?

\section{Method}

\section{Sample}

The sample consisted of 1126 pre-school teachers from 7 different geographical regions and 81 provinces of Turkey. Participants ranged in experience from zero to 43 years with a mean year of 14.02. Most of the participants identified as female (97.1\%), and the rest were male $(2.8 \%)$. Concerning education level, most of the participants' highest degree was a bachelor's degree $(n=823 ; 73.1 \%)$, while $123(10.9 \%)$ earned a master's degree, and $11(1.0 \%)$ participants earned a doctoral degree. Among them, 366 $(32.5 \%)$ of the participants reported working in a kindergarten classroom in a public school. In comparison, $463(41.1 \%)$ of the participants reported working in a public preschool. Also, $42(3.7 \%)$ of the participants reported working in a kindergarten classroom in a private school, while $254(22.6 \%)$ of the participants reported working in a private preschool. In terms of the children age group of the teachers' classroom, 455 (40.4\%) participants were working with 5-year-old children, 205 (18.2\%) participants were working with mixed-age children, 192 (17.1\%) participants were working with 6year old children, 181 (16.1\%) participants were working with 4-year old children, 83 (7.4\%) participants were working with 3-year old children, and $9(.8 \%)$ participants were working with 2-year old and under age group children. 
Table 1

Some Demographic Information about Participants

\begin{tabular}{|c|c|c|c|}
\hline Teachers' & & $\mathrm{n}$ & $\%$ \\
\hline \multirow{2}{*}{ Gender } & Female & 1093 & 97.1 \\
\hline & Male & 32 & 2.9 \\
\hline \multirow{7}{*}{ Education Level } & High School & 18 & 1.6 \\
\hline & Associate degree & 131 & 11.6 \\
\hline & Open Education Bachelor's degree & 19 & 1.7 \\
\hline & Bachelor's degree & 823 & 73.1 \\
\hline & Master's degree & 123 & 10.9 \\
\hline & Doctoral degree & 11 & 1.0 \\
\hline & Missing & 1 & .1 \\
\hline \multirow{5}{*}{ School Type } & Public kindergarten classroom & 366 & 32.5 \\
\hline & Public preschool & 463 & 41.1 \\
\hline & Private kindergarten classroom & 42 & 3.7 \\
\hline & Private preschool & 254 & 22.6 \\
\hline & Missing & 1 & .1 \\
\hline \multirow{7}{*}{$\begin{array}{l}\text { Age of children in } \\
\text { the classroom }\end{array}$} & Two and under of two & 9 & .8 \\
\hline & Three & 83 & 7.4 \\
\hline & Four & 181 & 16.1 \\
\hline & Five & 455 & 40.4 \\
\hline & Six & 192 & 17.1 \\
\hline & Mixed & 205 & 18.2 \\
\hline & Missing & 1 & .1 \\
\hline
\end{tabular}

\section{Instruments and Procedure}

For data collection, a survey was developed by the researchers. The survey's purpose was to determine preschool teachers' knowledge level about SD and its reflection on their practice in the classroom to develop a PD program. The intention was to reach as many preschool teachers as possible from all cities/regions of Turkey. The survey, which was carried out from March to May in 2020, consists of three parts: participants' demographics, views on EfS, and needs for implementing EfS in the preschool classrooms. In addition, there are questions about the participants' gender, teaching experiences, education, type of their institution, and children's age group of their classroom in the demographics section (Represented by seven questions).

Next parts aim to better understand participants' efficacies in knowing the SD concept, practicing EfS and their needs to implement EfS in their classroom. The second and third parts of the survey comprised 17 optional and close-ended questions (Six-point Likert scale from none/very poor/poor/fair/good/very good). Nine questions are also separated into three levels in the third part. These three levels are environmental, economic, and socio-cultural pillars of SD for every question in these 
nine. Because of the survey structure, it is more appropriate to collect data on the descriptive level. Sample questions from the second and third parts of the survey are presented below (Table 2).

\section{Table 2}

\section{Sample Questions from the Second and Third Parts of the Survey}

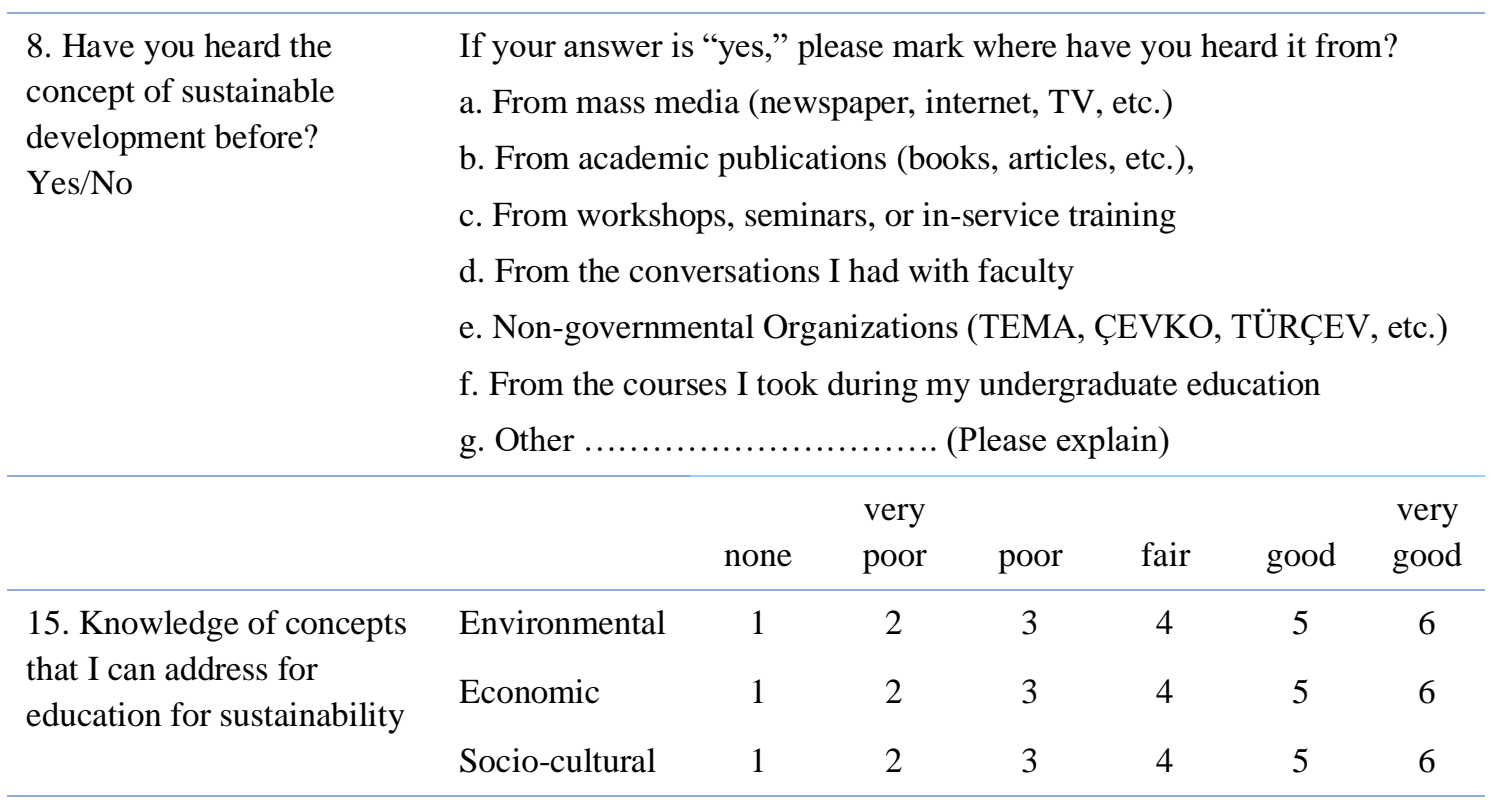

The survey was made available to participants via google forms for a threemonth interval. It was advertised through phone calls, social media such as Instagram, Facebook, Twitter, groups in messaging platforms; besides some phenomenon, preschool teachers in various social media tools advertised it for preschool teachers' attention. The survey has also been distributed to the number of participants via direct message who were asked to send the hyperlink to their colleagues, thus creating a snowball effect. The instrument's validity was granted from various field experts ranging from science education, preschool education, environmental education to educational measurement and evaluation.

\section{Data Analysis}

The data were analyzed via descriptive statistics because of the nature of the instrument. Most of the data were categorical in nature, so it was impossible to go further with inferential statistics. Instead, nonparametric Chi-square statistics were used in the analysis.

\section{Ethical Approval}

This study was approved with the Meeting Date and Number 28.05.2019/35853172-600 by the Social and Human Sciences Ethics Committee of Hacettepe University. 


\section{Results}

\section{Descriptive Statistics Results}

To investigate the teachers' needs for EfS, some questions were asked about their SD knowledge and enrollment in a course/seminar about SD. The first question was that "Have you heard the concept of SD before? If you heard, from where did you hear about the concept of sustainable development?" The results indicated that 362 (32.6\%) participants have not heard, but 764 (68.4\%) participants reported that they had heard the concept of SD. Most of them stated that they heard the concept of SD from mass media $(n=403 ; 36.2 \%)$ and academic publications $(n=385 ; 34.6 \%)$. Few of them reported hearing from NGOs (Non-Governmental Organizations) ( $\mathrm{n}=204 ; 18.3 \%)$, undergraduate courses $(n=143 ; 12.9 \%)$, and conversations with academics $(n=95$; $8.5 \%$ ). The remaining participants stated that they have heard from other sources.

The other question was, "Have you taking any training for EfS?" The analysis revealed that $164(14.6 \%)$ participants reported that they took training for EfS. The places where they took training include undergraduate and postgraduate courses at universities $(n=71 ; 6.4 \%)$, NGOs $(n=69 ; 6.2 \%)$, MoNE (Ministry of National Education) $(\mathrm{n}=35 ; 3.1 \%)$, private education institutions $(\mathrm{n}=23 ; 2.1 \%)$, and TUBITAK $(\mathrm{n}=20 ; 1.8 \%)$.

We also asked participants, "How would you evaluate your knowledge about SD?" The results showed that participants evaluated their knowledge of SD as poor at $27 \%$ and fair at 29\%. Examining the bar graph of the results shows that the participants' knowledge about SD is low. In the present study, participants were asked to evaluate their knowledge about the environmental, economic, and socio-cultural pillars of SD. The results showed very similar findings with the level of knowledge about SD. Figure 1 presents the bar graphs of the analyses.

Figure 1

Bar Graphs of the Analyses on the Knowledge about SD and Its Pillars

\begin{tabular}{|c|c|c|c|c|c|}
\hline & $\begin{array}{l}\text { Knowledge about SD } \\
(\%)\end{array}$ & \multicolumn{2}{|c|}{ for Environmental Pillar for Economical Pillar } & \multicolumn{2}{|c|}{$\begin{array}{l}\text { for Socio-Cultural Pillar } \\
\text { (\%) }\end{array}$} \\
\hline None & 19 & 19 & 20 & 20[ & \\
\hline Very Poor & 15 & 12 & 13 & 13[ & \\
\hline Poor & 27 & 27 & 31 & 28 & \\
\hline Foir & 29 & 28 & 26 & 27[ & \\
\hline Good & 9,6 & 12 & 8,9 & 11[ & \\
\hline Very Good & 1,2 & 2 & 1 & 1,6 & \\
\hline
\end{tabular}

On the other hand, examining the means and standard deviations of the scores concerning participants' general knowledge on SD and its pillars, it seems that knowledge about the environmental pillar of SD has a higher mean score among the pillars of SD (Table 2). 
Table 3

The Means and Standard Deviations of the Scores Concerning Participants' General Knowledge of SD and Its Pillars

\begin{tabular}{lcc}
\hline & $M$ & $S D$ \\
\hline Knowledge about SD & 1.99 & 1,31 \\
Knowledge about the environmental pillar of SD & 2.07 & 1.36 \\
Knowledge about the economic pillar of SD & 1.94 & 1.29 \\
Knowledge about the socio-cultural pillar of SD & 2.01 & 1.34
\end{tabular}

\section{EfS Activities}

In this part of the analyses, participants evaluated their knowledge on planning EfS activities, implementing skills, evaluating these EfS activities, and the concepts related to the three pillars of SD. The results indicated that about $22 \%$ reported not having any information about planning EfS activities. Furthermore, more than half of the participants reported themselves as "poor" or "fair" in this regard. This finding was found to be similar in all pillars of SD (Figure 2). When the participants' skills in implementing and evaluating EfS activities are examined, it can be seen that approximately $19 \%$ of the participants do not have any knowledge of all pillars. As a result of the analysis, it is seen that approximately $53 \%$ of them see themselves as poor or fair in implementing and evaluating skills (Figure 2). On the other hand, a small number of participants find themselves competent in these skills. The results also indicated that approximately one-third of the participants reported their knowledge of the concepts related to SD as "fair" and above (Figure 2).

Figure 2

Bar Graphs of the Analyses on Participants' Knowledge on Planning Efs Activities, Skills in Implementing, Skills in Evaluating These EfS Activities, and Information about the Concepts Related to Three Pillars of SD

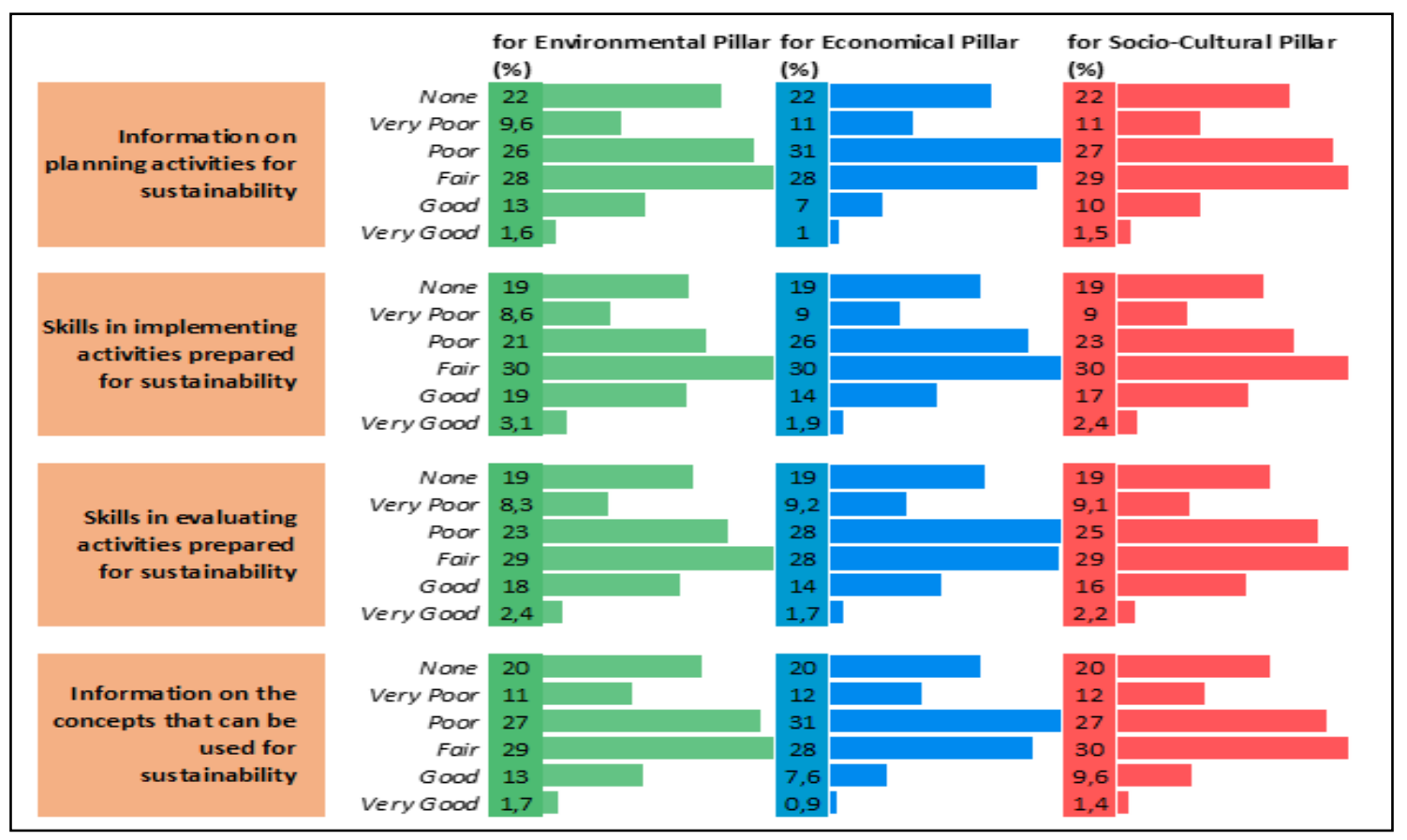


In this study, participants were asked about evaluating their skills for organizing learning centers or using outdoor learning environments regarding EfS. According to the results, about $18 \%$ of the participants found themselves inadequate in these skills, while about $47 \%$ reported that they see themselves as "fair" and above proficiency. (Figure 3).

Figure 3

Bar Graphs of the Analyses on Participants' Skills for Organizing Learning Centers and Outdoor Learning Environments

\begin{tabular}{|c|c|c|c|c|c|c|}
\hline \multirow{7}{*}{$\begin{array}{r}\text { Skills for organizing } \\
\text { learning centers for } \\
\text { sustainability }\end{array}$} & & \multicolumn{3}{|c|}{$\begin{array}{l}\text { for Environmental Pillar for Economical Pillar } \\
\begin{array}{ll}\text { (\%) } & \text { (\%) }\end{array}\end{array}$} & \multicolumn{2}{|c|}{$\begin{array}{l}\text { for Socio-Cultural Pillar } \\
\text { (\%) }\end{array}$} \\
\hline & None & 18 & 18 & & 18 & \\
\hline & Very Poor & 8,6 & 9,4 & & 8,6 & \\
\hline & Poor & 22 & 27 & & 24 & \\
\hline & Fair & 31 & 30 & & 31 & \\
\hline & Good & 18 & 13 & & 15 & \\
\hline & Very Good & 3,6 & 2,6 & & 3,3 & \\
\hline & None & 18 & 19 & & 18 & \\
\hline Skills for using out-of- & Very Poor & 8,5 & 8,6 & & 9,3 & \\
\hline school learning & Poor & 24 & 29 & & 25 & \\
\hline environments for & Foir & 30 & 29 & & 30 & \\
\hline sustainability & Good & 16 & 12 & & 14 & \\
\hline & Very Good & 4 & 3,1 & 1 & 3,6 & \\
\hline
\end{tabular}

\section{Family Involvement}

Another issue was participants' skills on family involvement for SD. According to the results, only less than $20 \%$ of the participants consider themselves competent regarding family involvement. Moreover, $19 \%$ of them stated that they do not have any skills. Figure 4 represents some graphs to show the findings of family involvement.

Figure 4

Bar Graphs of the Analyses on the Knowledge about SD and Its Pillars

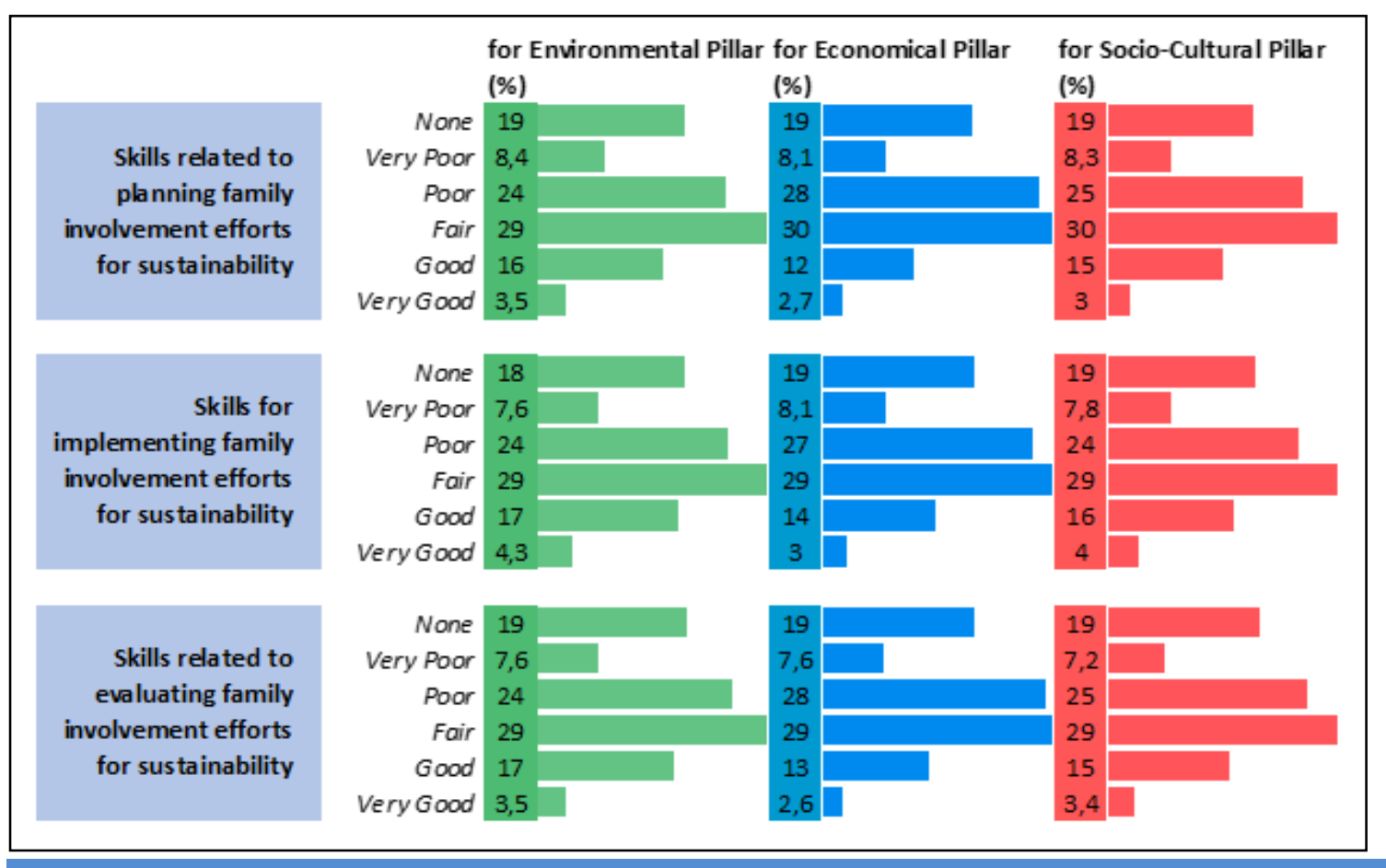

C 2021 AKU, Kuramsal Eğitimbilim Dergisi - Journal of Theoretical Educational Science, 14(4), 586-604 
In the present study, the participants answered two additional questions about inservice training on taking EfS. As a result, almost all participants stated that they needed in-service training on EfS ( $\mathrm{n}=1068 ; 94.8 \%)$, and most of the participants $(90.0 \%)$ also stated that they would enroll in in-service training for EfS (Figure 5).

Figure 5

Bar Graphs of the Analyses on the Knowledge about SD and Its Pillars

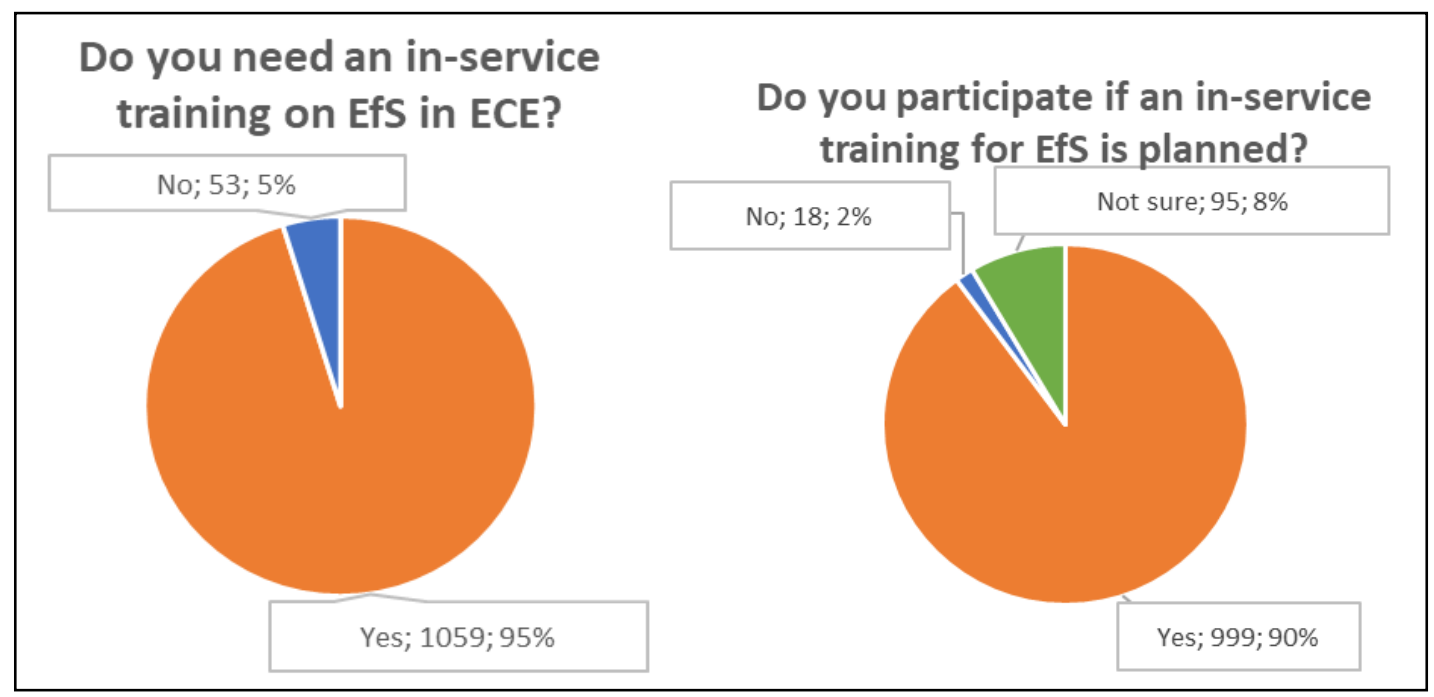

\section{Chi-Square Test Results}

The study's last findings were related to whether participants' answers on hearing SD before differing regarding the types of schools they worked in. The chisquare for independence was run after checking the assumptions for it such as minimum expected cell frequency. The test results firstly indicated that this assumption was not violated and all expected cell sizes are greater than 5 (43.15). The results also revealed that relation between these variables was significant, $X^{2}(1, \mathrm{~N}=1125)=13.131, p<.01$. It means that participants' answers have significantly differed concerning the schools' type that they were working. It is observed that a higher proportion of participants in private schools have heard of SD compared to public schools (Table 4).

Table 4

The Number of Participants' Hearing SD and the Type of Schools That Participants Were Working in

\begin{tabular}{lcc}
\hline & \multicolumn{2}{c}{ Have you heard the concept of SD before? } \\
\cline { 2 - 3 } & Yes & No \\
\hline Public & $n=538(64.90 \%)$ & $n=291(35.10 \%)$ \\
Private & $n=226(76.35 \%)$ & $n=70(23.65 \%)$ \\
\hline
\end{tabular}

\section{Discussion and Conclusion}

Children are regarded as individuals who hold the skills to participate in problem-solving and decision-making processes of recent environmental, social- 
cultural, and economic issues. These changing perspectives towards children made them active agents for change to be involved in activities related to SD (Davis, 2010; Duhn, 2012; UNESCO, 2008;). Preschool teachers are seen as essential dynamics to promote SD in societies starting from the early years (Henderson \& Tilbury, 2004; Kahriman Pamuk \& Olgan, 2020). Today's preschool teachers need to understand better the theory and practices of EfS to make connections between children and the sustainable world. In this regard, the current study aims to grasp preschool teachers' general knowledge on SD and its pillars, their experience in preparing and implementing EfS activities, and their PD needs for EfS as a first stage of developing PD modules.

According to the present study's initial findings, but $68.4 \%$ of them have heard the concept of SD before, $32.6 \%$ of preschool teachers have not heard the concept of SD. These findings revealed that most of the preschool teachers acknowledge the term SD. Preschool teachers also reported that they heard about SD mainly by mass media (36.2\%) and academic publications (34.6). Other critical resources were defined as NGOs $(18.3 \%)$, undergraduate courses $(12.9 \%)$, and conversations with academics $(8.5 \%)$. Similarly, $68 \%$ of the Korean preschool teachers reported that they heard about SD, and they indicated workshops and seminars (28\%), mass media sources (19\%), and academic publications (19\%) as the primary source for this (Park et al., 2016).

When comparing with the findings of previous studies, it may be concluded that SD is an emerging issue in Turkish early childhood education. Indeed, Haktanır et al. (2010) reported that pre-school teachers and pre-service preschool teachers did not know about the concepts of sustainability and SD ten years ago. Although SD is becoming more popular in early childhood education and preschool teachers reported that they believe in the importance of SD for the future, the whole meaning and underpinned ideas were not comprehended (Kahriman Öztürk \& Olgan, 2016). Hedefalk et al. (2015) also highlighted the limited comprehension of preschool teachers about SD. Researchers reported that preschool teachers perceive SD with only the environmental pillar. Similarly, Inoue et al. (2016) concluded that though the Australian early childhood curriculum covers the issues of SD, the teachers do not have enough information and practices about EfS. Researchers suggested that in-service training opportunities related to EfS could be provided to teachers to promote sustainabilityrelated understandings and practices.

Like the relevant literature, the current study also exhibits limited SD knowledge of preschool teachers. According to the findings, participants evaluated their knowledge of $\mathrm{SD}$ as poor at $27 \%$ and fair at $29 \%$. It means that their level of knowledge is considered low. Examining the findings related to SD's pillars, participants evaluated their knowledge about the environmental, economic, and socio-cultural pillars of SD as low too. As mentioned above, preschool teachers' knowledge about SD is critical since they are responsible for introducing SD to children (World Commission on Environment and Development [WCED], 1987). Flogaitis and Agelidou (2003) and Bursjöö (2011) added that preschool teachers consider the lack of SD knowledge as a barrier to implementing EfS activities. Therefore, limited SD knowledge is one of the reported barriers to applying EfS the preschool classrooms. In connection with this argument from relevant literature, participants of the current study also evaluated their knowledge on planning EfS activities and skills in implementing and evaluating these EfS activities for three pillars of SD as poor or fair. Kahriman Pamuk and Olgan (2018) 
defined EfS activities as in-class and outdoor learning processes run by preschool teachers with children's participation to promote SD.

There is a worldwide attempt to promote teachers' sustainability-related understandings and practices. Reorienting education programs towards SD could be a way of encompassing teachers' roles in EfS (Sterling \& Huckle, 2014). In this regard, they must understand how teachers perceive SD and what they need to associate EfS into the existing curriculum. The national preschool education program (MoNE, 2013) implicitly refers to SD via its objectives and indicators. For example, "respect for diversity," "reflect on different cultural features," and "maintain aesthetic values" are appropriate objectives that are also critical features for sustainability. However, the current study's findings also revealed that preschool teachers do not know SD-related concepts in the national preschool education curriculum.

Similarly, regarding the implementation of EfS activities, participants were examined about their knowledge on the concepts related to SD, skills for organizing learning centers, and outdoor learning environments. Organizing learning centers and using outdoor learning environments regarding EfS were seen as challenging tasks for the participants. About one-fifth of them do not know how to organize learning centers and use outdoor learning environments. Furthermore, half of them do not trust enough their skills to do these tasks. This result is not surprising since most participants noted that they had poor and fair knowledge about SD. In these circumstances, teachers could not create learning centers and use outdoor environments in the face of EfS and SD. This might be directly linked to teachers' conceptions of EfS to be limited (Dyment et al., 2015), teachers' value, and a lack of awareness of the priority of EfS (Nicholls \& Thorne, 2017).

On the other hand, according to teachers, they do not have enough resources to pick up materials for the learning centers independently of SD and EfS in Turkey (Demirci \& Şıvgın, 2017; Özyürek \& Kılınç, 2015). Therefore, teachers might not search how to organize, what materials use and how to use them for EfS. However, according to Prescott (1987), a well-organized environment encourages children to follow themselves or their curiosity. Besides, the environment affects how children move, behave, and it also determines how, what and where children will play (Hoorn et al., 1993). Moreover, it offers an educational experience and a visual representation of the value of school or teacher values (Barr et al., 2014).

Furthermore, teachers reported they did not have sufficient skills to organize learning centers and outdoors for EfS in the present study. On the other hand, according to Davis (2010), the outdoor environment is a learning setting and a resource for children. Therefore, they need exposure to sustainable lifestyle practices to foster their capacities (Ginsburg \& Audley, 2020). Furthermore, Kahriman Pamuk and Olgan (2018) addressed that eco and ordinary preschools had different physical conditions, but there was no significant difference in their classroom practices. Thus, organizing the environment might be related to teachers' attitudes towards safety, nature, and place (Padilla-Walker \& Nelson, 2012). Otherwise, the physical environment influences how teachers think and practice implementing EfS practices (Henderson \& Tilbury, 2004). Thus, it is imperative to figure out their pedagogical practices regarding EfS (Ginsburg \& Audley, 2020) and guide them to improve their skills, knowledge, ideas, and practices about EfS to organize and use the indoor and outdoor learning settings. 
Family involvement was another critical issue for this study. According to the results, one-fifth of them consider themselves competent regarding family involvement efforts for SD. Moreover, $19 \%$ of them stated that they do not have any skills for all SD pillars. The dynamics of the family impact the transition of children's behaviors and knowledge to the home (Lee et al., 2019) because children might have the agency to adjust both at school and home (Ginsburg \& Audley, 2020). According to Bandura (1986), parents are a social context for children's learning. Borg (2019) stated that parents are sources of knowledge for children to learn other children's economic situations. Educators recognized that more powerful messages could be delivered when parents participated in children's sustainability awareness (Morris et al., 2016). Güler Y1ldiz et al. (2017) found that children's behaviors were shaped in terms of doing activities at home because the skills about EfS ought to be part of their daily lives (Renton \& Butcher, 2010). Therefore, teachers might support, lead and educate parents about SD (Güler Yıldız et al., 2017). Hence, skills and knowledge about planning, implementing, and evaluating parent involvement activities are critical for cooperating to lead children about SD and EfS. On the other hand, parental beliefs about the outdoors associate with risk (Knight, 2013; Michek et al., 2015), so it is a barrier to EfS. Therefore, family involvement is critical especially using the outdoor environment as a resource. In the present study, most of the teachers have poor or fair skills for planning, implementing, and evaluating the family involvement activities about the three pillars of SD. This might be linked to knowledge and skills for planning EfS activities and about $22 \%$ reported that they did not have any information about planning EfS activities. Therefore, teachers need to know how to do these. This process is vital considering not only for children, but also for society (Davis et al., 2008; McNichol et al., 2011).

The school type could be seen as a significant part of gaining awareness for SD. The last findings were related to whether participants' answers on hearing SD before differing regarding the types of schools they worked in. The results indicated that participants' answers differed concerning the type of school they were working at. It is observed that a higher proportion of participants in private schools heard of SD compared to public schools. This finding was also reported by Korkmaz and Güler Yildı (2017) that there was a difference between public and private Eco-Schools regarding EfS practices in favor of private Eco-Schools. Teachers working in private schools were more competent for the environmental pillar of SD, but they were the same within the socio-cultural pillar. A possible explanation might be that SD activities generally contribute to the environmental pillar (Korkmaz \& Güler Yıldız, 2017).

Consequently, there is a widespread bolster for EfS, but it is still challenging for planning and implementation in preschool classrooms. As expected, almost all participants stated their needs for in-service training on EfS and their willingness to participate. This study's findings revealed that a small portion of participants took training on EfS throughout undergraduate and postgraduate courses at universities, NGOs, MoNE, private education institutions, and TUBITAK. Kahriman Öztürk and Olgan (2016) reported the need for in-service training on EfS. Similarly, Inoue et al. (2016) highlighted that EfS related in-service training such as courses, lessons, seminars, and so on would positively affect preschool teachers' views about EfS. 


\section{Limitations}

The reader should bear in mind that the study is based on preschool teachers' self-report to determine their needs about EfS as a first step for developing a PD. Establishing how teachers plan their activities, how activities are implemented, and how children use learning centers and outdoor environments are beyond the current study's scope. Therefore, addressing them may provide more valid information on this issue for future studies. Also, it might exhibit the pedagogical content knowledge of teachers. Secondly, it is beyond the current study's scope to explore what teachers know about EfS and how they translate knowledge into practice in the classroom. Exploring these processes might be helpful to guide teachers in improving their practices. Thirdly, some teachers reported that they have good and excellent knowledge and skills on planning, implementing, and evaluating SD activities for both children and family involvement, organizing learning centers, and using outdoor environments. Information on how they execute these was not the focus of this study. Future research might reveal these so teachers could see the best practices. Despite its limitations, the study certainly adds to what teachers say their knowledge and skills about SD and EfS activities regarding SD pillars.

\section{Acknowledgement}

This research is the first stage of a bilateral project between Turkey and South Korea that was initiated to contribute significantly to the EfS policies and practices of both countries and supported by TÜBİTAK (The Scientific and Technological Research Council of Turkey). The joint development of teacher training modules between Turkey and South Korea is the first stage of this project, and, as an initial step professional development, needs of preschool teachers in Turkey were investigated.

\section{Statement of Responsibility}

All authors have participated sufficiently in the work to take public responsibility for the content, including participation in the concept, design, analysis, writing, or revision of the manuscript. Furthermore, each author certifies that this manuscript has not been and will not be submitted to or published in any other publication before its appearance in the Journal of Theoretical Science.

\section{References}

Australian Education for Sustainability Alliance (AESA). (2014). Education for sustainability and the Australian curriculum project: Final report for research phases 1 to 3 . http://aries.mq.edu.a/ublication/the/ducatio/fS-in-AustCurriculum.pdf

Bandura, A. (1986). Social foundations of thought and action: A social cognitive theory. Eaglewood Cliffs, NJ: Prentice-Hall.

Barr, S. K., Cross, J. E., \& Dunbar, B. H. (2014). The whole school sustainability framework. https://centerforgreenschools.org/sites/default/files/resourcefiles/Whole-School_Sustainability_Framework.pdf

Bascopé, M., Perasso, P., \& Reiss, K. (2019). Systematic review of education for sustainable development at an early stage: Cornerstones and pedagogical 
approaches for teacher professional development. Sustainability, 11(3), 719. https://doi.org/10.3390/su11030719

Berglund, T., \& Gericke, N. (2016). Separated and integrated perspectives on environmental, economic, and social dimensions an investigation of student views on sustainable development. Environmental Education Research, 22(8), 1115-1138, https://doi.org/10.1080/13504622.2015.1063589

Bonnett, M. (1999). Education for sustainable development: A coherent philosophy for environmental education? Cambridge Journal of Education, 29(3), 313-324. https://doi.org/10.1080/0305764990290302

Borg, C., Gericke, N., Höglund, H., \& Bergman, E. (2014). Subject- and experiencebound differences in teachers' conceptual understanding of sustainable development. Environmental Education Research, 20(4), 526-551. https://doi.org/10.1080/13504622.2013.833584

Borg, F. (2019). Economic (in)equality and sustainability: Preschool children's views of the economic situation of other children in the world. Early Child Development and Care, 189(8), 1256-1270. https://doi.org/10.1080/03004430.2017.1372758

Brundtland, G. H. (1988). Världskommissionen för miljö och utveckling [World commission on environment and development: our common future]. Translated and edited by B. Hägerhäll, 408. Stockholm: Prisma.

Bursjöö, I. (2011). How student teachers form their educational practice in relation to sustainable development. Utbildning \& Demokrati-tidskrift för didaktik och utbildningspolitk, 20(1), 59-78.

Centre for Environment and Sustainability. (2008). The gothenburg recommendations on education for sustainable development. Chalmers University of Technology and University of Gothenburg. Gothenburg: Sweden.

Davis, J. (2010). What is early childhood education for sustainability? In J. M. Davis (Ed.), Young children and the environment (pp. 21-42). Port Melbourne, VIC: Cambridge University Press.

Davis, J., Miller, M., Boyd, W., \& Gibson, M. (2008). The impact and potential of water education in early childhood care and education settings: A report of the rous water early childhood water aware centre program, Brisbane: QUT.

Demirci, F. G., \& Şıvgın, N. (2017). Okul öncesi öğretmenlerinin öğrenme merkezleri ile ilgili uygulama ve görüşleri. [Practices and opinions of pre-school teachers about learning centers]. Electronic Turkish Studies, 12(18), 271-292. https://doi.org/10.7827/TurkishStudies.12092

Duhn, I. (2012). Making 'place'for ecological sustainability in early childhood education. Environmental Education Research, 18(1), 19-29. https://doi.org/10.1080/13504622.2011.572162

Duncan, E. (2011). Report part 2-ESD in practice. Norway: OMEP.

Dyment, J. E., Davis, J. M., Nailon, D., Emery, S., Getenet, S., McCrea, N., \& Hill, A. (2014). The impact of professional development on early childhood educators' confidence, understanding and knowledge of education for sustainability. Environmental Education Research, 20(5), 660-679. https://doi.org/ 10.1080/13504622.2013.833591 
Dyment, J. E., Hill, A., \& Emery, S. (2015). Sustainability as a cross-curricular priority in the Australian curriculum: A Tasmanian investigation. Environmental Education Research, 21, 1105-1126. https://doi.org/10.1080/13504622.2014.966657

ECEESDPD. (2020). Integrating sustainable development into early childhood education: An effort through modules and professional development. Bilateral Cooperation Project (TUBITAK-NRF). https://www.eceesdpd.com/

Elliott, S., Ärlemalm-Hagsér, E., \& Davis, J. (Eds.). (2020). Researching early childhood education for sustainability challenging assumptions and orthodoxies. NY: Routledge.

Elliott, S., \& Davis, J. (2009). Exploring the resistance: An Australian perspective on educating for sustainability in early childhood. International Journal of Early Childhood, 41(2), 65-77. https://doi.org/10.1007/BF03168879

Engdahl, I. (2015). Early childhood education for sustainability: The OMEP world project. International Journal of Early Childhood, 47(3), 347-366. https://doi.org/10.1007/s13158-015-0149-6

Engdahl, I., \& Rabušicová, M. (2011). Education for sustainable development in practice: World organisation for early childhood education (OMEP). http://old.worldomep.org/files/1343134_wareport-omep-esd-in-practice-2011-1.pdf

Flogaitis, E., \& Agelidou, E. (2003). Kindergarten teachers' conceptions about nature and the environment. Environmental Education Research, 9(4), 461-478. https://doi.org/10.1080/1350462032000126113

Ginsburg, J. L., \& Audley, S. (2020). "You don't wanna teach little kids about climate change": Beliefs and barriers to sustainability education in early childhood. International Journal of Early Childhood Environmental Education, 7(3), 42-61.

Güler Yıldız, T., Öztürk, N., İlhan İyi, T., Aşkar, N., Banko Bal, Ç., Karabekmez, S., \& Höl, Ş. (2021). Education for sustainability in early childhood education: A systematic review. Environmental Education Research. https://doi.org/10.1080/13504622.2021.1896680

Güler Yıldız, T., Simsek, P. O., Eren, S., \& Aydos, E. H. (2017). An analysis of the views and experiences of children who are 48-66 months old, their parents, and teachers about "sustainable development". Educational Sciences-Theory \& Practice, 17(2), 653-677. https://doi.org/10.12738/estp.2017.2.0013

Haktanır, G., Güler, T., Yılmaz, A., \& Kurtulmuş, Z. (2010). "Perceptions of Turkish early childhood pre-service teachers about sustainable development". OMEP XXVI. World Congress, 11-13 August 2010, Göteborg/Sweden.

Hedefalk, M., Almqvist, J., \& Östman, L. (2015). Education for sustainable development in early childhood education: A review of the research literature. Environmental Education Research, 21(7), 975-990. https://doi.org/10.1080/13504622.2014.971716

Henderson, K., \& Tilbury, D. (2004). Whole-school approaches to sustainability: An international review of sustainable school programs. Report. The Australian Research Institute in Education for Sustainability (ARIES) for The Department of the Environment and Heritage, Australian Government. ISBN, 1(86408), 979. 
Hill, A., McCrea, N., Emery, S., Nailon, D., Davis, J., Dyment, J., \& Getenet, S. (2014). Exploring how adults who work with young children conceptualise sustainability and describe their practice initiatives. Australasian Journal of Early Childhood, 39(3), 14-22. https://doi.org/10.3316/informit.662244248093552

Hoorn, J. V., Nourot, P., Scales, B., \& Alward, K. (1993). Play at the center of the curriculum. New York, NY: Macmillan.

Inoue, M., O’Gorman, L., \& Davis, J. (2016). Investigating early childhood teachers' understandings of and practices in education for sustainability in Queensland: A Japan-Australia research collaboration. Australian Journal of Environmental Education, 32(02), 174-191. https://doi.org/10.1017/aee.2016.4

Kahriman, D. (2016). Comparison of early childhood education educators' education for sustainable development practices across eco versus ordinary preschools [Unpublished doctoral dissertation]. Ankara: Middle East Technical University Institute of Social Sciences.

Kahriman Öztürk, D., \& Olgan, R. (2016). Analysis of pre-school teachers' views on the importance of education for sustainable development by means of location and household type in childhood. International Journal of Environmental and Science Education, 11(13), 6303-6313.

Kahriman Pamuk, D., \& Olgan, R. (2018). Teacher practices and preschool physical environment for education for sustainable development: Eco vs ordinary preschools. Mersin Üniversitesi Eğitim Fakültesi Dergisi, 14(2), 669-683. https://doi.org/10.17860/mersinefd.391312

Kahriman Pamuk, D., \& Olgan, R. (2020). Comparing predictors of teachers' education for sustainable development practices among eco and non-eco preschools. Education and Science, 45(203), 327-345. https://doi.org/10.15390/EB.2019.8774

Knight, S. (2013). Risk \& adventure in early years' outdoor play: Learning from forest schools. Oxford: Sage Publications.

Korkmaz, A., \& Güler Yıldız, T. (2017). Assessing preschools using the eco-schools program in terms of educating for sustainable development in early childhood education. European Early Childhood Education Research Journal, 25(4), 595611. https://doi.org/10.1080/1350293x.2017.1331074

Lee, R. E., Soltero, E. G., Ledoux, T. A., Sahnoune, I., Saavadra, F., Mama, S. K., \& McNeill, L. H. (2019). Sustainability via active garden education: Translating policy to practice in early care and education. Journal of School Health, 89(4), 257266. https://doi.org/10.1111/josh.12734

McNichol, H., Davis, J. M., \& O’Brien, K. R. (2011). An ecological footprint for an early learning centre: Identifying opportunities for early childhood sustainability education through interdisciplinary research. Environmental Education Research, 17(5), 689-704. https://doi.org/10.1080/13504622.2011.572161

Michek, S., Nováková, Z., \& Menclová, L. (2015). Advantages and disadvantages of forest kindergarten in Czech Republic. Procedia-Social and Behavioral Sciences, 171, 738-744. https://doi.org/10.1016/j.sbspro.2015.01.186

Ministry of National Education [MoNE]. (2013). Preschool education program. http://tegm.meb.gov.tr/dosya/okuloncesi/ooproram.pdf 
Morris, H., Skouteris, H., Edwards, S., Rutherford, L. M., Cutter-Mackenzie, A., O'Connor, A., Mantilla, A., Huang, T. T. K., Lording, K. M., \& Williams-Smith, J. (2016). Feasibility of conducting a randomized trial to promote healthy eating, active play and sustainability awareness in early childhood curricula. Early Child Development and Care, 186(11), 1752-1764. https://doi.org/10.1080/03004430.2015.1131158

Nespor, J. (1987). The role of beliefs in the practice of teaching. Journal of Curriculum Studies, 19(4), 317-328. https://doi.org/10.1080/0022027870190403

Nicholls, J., \& Thorne, M. (2017). Queensland teachers' relationship with the sustainability cross-curriculum priority. Australian Journal of Environmental Education, 33(3), 189-200. https://doi.org/10.1017/aee.2018.1

OMEP [Organization Mondiale Pour L'Education Prescolaire]. (2020). Education for sustainable development world project. http://eceresourcebank.org/index.php?hCode=PROJECT_04_01

Özyürek, A., \& Kılınç, N. (2015). Okul öncesi eğitim kurumlarındaki öğrenme merkezlerinin çocukların serbest oyun davranışları üzerine etkisi [The Effect of learning centers on the children's leisure time activity behaviors at pre-school institutions]. Karabük Üniversitesi Sosyal Bilimler Enstitüsü Dergisi, 5(2), 125138.

Padilla-Walker, L. M., \& Nelson, L. J. (2012). Black hawk down? Establishing helicopter parenting as a distinct construct from other forms of parental control during emerging adulthood. Journal of Adolescence, 35(5), 1177-1190. https://doi.org/10.1016/j.adolescence.2012.03.007

Panatsa, V. M., \& Malandrakis, G. (2018). Student teachers' perceptions about the social pillar of urban sustainability. International Journal of Sustainability in Higher Education, 19(5), 998-1018. https://doi.org/10.1108/IJSHE-09-2017-0162

Park, E., Kim, H., \& Yu, S. (2016). Perceptions and attitudes of early childhood teachers in Korea about education for sustainable development. International Journal of Early Childhood, 48(3), 369-385. https://doi.org/10.1007/s13158-0160176-y

Pepper, C., \& Wildy, H. (2008). Leading for sustainability: Is surface understanding enough? Journal of Educational Administration, 46(5), 613-629. https://doi.org/10.1108/09578230810895528

Prescott, E. (1987). The environment as organizer of intent in child-care settings. In Spaces for children (pp. 73-88). Springer, Boston, MA.

Presidency of the Strategy and Budget (2019). The eleventh development plan (20192023).

https://www.sbb.gov.tr/wpcontent/uploads/2020/03/On_BirinciPLan_ingilizce_SonBaski.pdf

Renton, Z., \& Butcher, J. (2010). Securing a sustainable future for children and young people. Children and Society, 24, 160-166. https://doi.org/10.1111/j.10990860.2009.00280.x

Sterling, S., \& Huckle, J. (Eds.) (2014). Education for sustainability. Routledge.

TEMA (Turkish Foundation for Combating Soil Erosion, for Reforestation and the Protection of Natural Habitats). (2018). Education programs of the Turkish 
foundation for combating soil erosion, for reforestation and the protection of natural habitats. https://www.tema.org.tr/calismalarimiz/egitim/doga-egitimprogramlari/minik-tema

Turkish Ministry of Environment and Urbanization. (2019). Zero waste. http://zerowaste.gov.tr/

Turkish Ministry of Environment and Urbanization. (2020). Save your food. https://www.gidanikoru.com/

Uğraş, M., \& Zengin, E. (2019). Sınıf öğretmeni adaylarının sürdürülebilir kalkınma için eğitim ile ilgili görüşleri. Kuramsal Eğitimbilim Dergisi, 12(1), 298-315. https://doi.org/10.30831/akukeg.442751

UN. (2015). Transforming our world: The 2030 agenda for sustainable development. https://www.un.org/sustainabledevelopment/sustainable-development-goals/

UNESCO. (2002). Education for sustainability_From Rio to Johannesburg: Lessons learnt from a decade of commitment. Paris: Author.

UNESCO. (2005a). United Nations decade of education for sustainable development (2005-2014). http://portal.unesco.org/education/admin/ev.php

UNESCO. (2005b). International implementation scheme. http://unesdoc.unesco.org/images/0014/001486/148654E.pdf

UNESCO. (2006). Framework for the UNDESD international implementation scheme. Paris: UNESCO.

UNESCO. (2008). EFA-ESD dialogue: Educating for a sustainable world. Paris: UNESCO.

UNESCO. (2014). Roadmap for implementing the global action programme on education for sustainable development. Paris, France. http://unesdoc.unesco.org/images/0023/002305/230514e.pdf

World Commission on Environment and Development [WCED]. (1987). Our common future. Oxford: Oxford University Press. 